\title{
Diaspora by Design? Multiple Allegiances and Belonging in Contemporary Global Catholicism
}

\author{
Ester Gallo
}

The article explores the semantic and experiential meanings of diaspora within the context of global Catholicism. Drawing from research conducted in Italy, the United Kingdom, and Turkey with the reformist movement known as the Neocatechumenal Way (NCW), the analysis delves into the broader question of how the refashioning of global religions is transforming the relation between people, places, and belonging and is contributing to the emotional, practical, and organizational dimensions of diaspora. The discussion first delves into the role of new missionary subjects in cementing a new proximity between the world Catholic population and Mediterranean and Middle-Eastern holy centers of Catholicism. Second, it draws from current definitions of diaspora to consider how a diasporic identity is constructed by dispersed NCW communities in daily lives and rituals. The analysis goes beyond the dimensions of ethnicity and migration, and claims the need to reassert the importance of religious case studies in our understanding of contemporary diaspora. The case of the NCW holds relevance here, insofar as it unravels how a reformist movement, by gaining progressive institutionalization within the Catholic Church, is also undermining some of its consolidated features by creating renewed cartographies of religious belonging. The article argues that the traditional semantics of diaspora - those developed in religious paradigms - deserve renewed attention in the social sciences in order to map ongoing transformations in world religions, and the attendant shifting identifications that characterize even more institutionalized religions like Catholicism.

Key words: religion, Catholicism, diaspora, kinship, belonging

Ester Gallo, "Diaspora by Design? Multiple Allegiances and Belonging in Contemporary Global Catholicism," Diaspora 19, 1 (2010): 51-73. (C) 2016 Diaspora: a journal of transnational studies. 
Diaspora 19:1 (2010) / published Fall 2016

Il Cammino é per I lontani.

[The Way is for distant ones]

Popular Neocatechumenal saying.

I met Luana ${ }^{1}$ for the first time in Perugia (Central Italy) after her return from a mission in Cameroon. She had spent a few months in the country with her husband Mario to support the work of local parishes belonging to the reformist global Catholic movement known as the Neocatechumenal Way. Luana was busy finalizing a report on the progress of her work in Africa but, after much negotiation, she received me in a recently built palatial white church that hosted one of the more numerous and certainly most active Neocatechumenal communities in the city. When I asked Luana about her mission in Cameroon, she explained the motivation for her journey there by referring to a personal move from "sinful life" to "religious truth." She depicted herself as a person who until a few years before had lived away from Catholicism, as a "sinner who was losing any real point of reference in life." She had been about to divorce her husband, she had barely attended church, and she used to make fun of devout people. Now that she had had the opportunity to discover "real" Catholicism, however, she had chosen to bring her experience to people who were still "living in the darkness."

For Luana, as for many other members, there was no real difference between a person living in one of the centers of Catholicism, like Italy, and a person living in Cameroon. She used the notion of being "distant from religion" in a way that merged existential and spatial meanings: in her rendition, the Neocatechumenal Way should ideally (if not exclusively) attract people who had not been socialized into conventional Catholicism, on the principle that it was easier to build up from "ground zero," that is, by appealing to people who had lived "distant from religion," than to dismantle erroneous beliefs and practices among people who were believing Catholics. Similarly, the renewed Catholicism of the Neocatechumenal Way should be brought to devotees living geographically far away from the centers of religion (Italy, Spain, and Israel), or where "other religions" had kept people away from the truth of Christ.

Belonging to the movement thus involved a double mission: to regenerate oneself and to instill new forms of belonging in "distant" believers. In this light, membership in a local parish in Italy was coterminous with the duty to achieve new conversions in so-conceived peripheral locations. Being "outside The Way" meant to be "in exile" from the truth of religion and the real sense of life; by contrast, membership in the movement signified being united with other people across sometimes large distances for a common purpose. But it also could strengthen the feeling of being misunderstood and discriminated against by the surrounding society. 
These brief ethnographic reflections offer a way into the broader question of how and to what extent the refashioning of global religions transforms the relationship between people, places, and belonging (Beyer 2003; Coleman 2000; Csordas 2007; Wolffe 2002), and contributes to the emotional, practical, and organizational dimensions of diasporas in the contemporary world (cf. Cohen 2008, 155-6). In this article I explore the semantics and the experiential meanings of "diaspora" within the context of the Neocatechumenal Way (referred to here as either NCW or The Way). The goal here is twofold. First, I map how the movement's ethos and the work of "itinerant" and "missionary families" design new diasporic sentiments among devotees worldwide. Second, I draw from current definitions of diaspora (Cohen 1997, 2008) to consider how a diasporic identity is constructed by dispersed NCW communities in daily lives and rituals. My analysis goes beyond the dimensions of ethnicity and migration (see Cohen 1997, 2008; Hinnells 1997; Vertovec 1997), and underlines the need to reassert the importance of religion in our understanding of contemporary diaspora. The case of the NCW is significant here, insofar as it shows how a reformist movement, by progressively gaining acceptance from the Catholic Church, also undermines some of Catholicism's institutional features by creating renewed cartographies of religious belonging. Overall, the article argues that the traditional semantics of diaspora deserve renewed attention within the social sciences in order to analyze ongoing transformations in world religions, and the shifting identifications between people, places, and belonging that characterize highly institutionalized religions like Catholicism.

\section{Researching the Neocatechumenal Way}

The NCW is a Catholic movement that was founded in Madrid (Spain) in 1964 by Kiko Argüello and Carmen Hernández as a positive response to the Second Vatican Council (1962). ${ }^{2}$ In line with the Conciliar ethos, the movement aims at embodying a renewed Church, able to "enflesh" the reality it seeks to communicate and to be "close to people's everyday life" (Himes 2006, 17). It aims to purify the institutional credibility of Catholicism, and radically to transform at a global level the way in which this religion is understood and practiced. Initially established to re-evangelize European countries where processes of secularization appeared to be in the ascendant, the NCW accounts today for 40 thousand communities worldwide with nearly 1,200 itinerant families and a growing number of members (one million at current estimates). The Way is particularly rooted in Italy, Spain, Ireland, Poland, and Austria. It is also gaining strength in the United Kingdom (mainly London) and Germany, and has considerably expanded in Asia (Philippines and India), South America (Brazil, Mexico, Venezuela, and Colombia), and Africa (Zambia, Cameroon, Ivory Coast, and Congo). In January 2012, 
China, Scotland, and Turkey were declared new target destinations for the creation or strengthening of existent communities. The movement is particularly strong in urban contexts: cities are considered places where the relationship between parishes and families has been weakened by modernization, and they consequently emerge as the primary target of evangelization. The presence of the NCW at the urban level is also expressed through the construction of impressive churches, often funded, furnished, and decorated through the contributions of people from different parts of the world.

Initially regarded with suspicion by Catholic institutions-and still condemned as heretical by many - the NCW's global success in mobilizing Catholics has meant a slow process of institutionalization, eventually ratified in the approval of the Official Statute in 2008. This Statute recognizes The Way as an "integral part of Christian education" within the Catholic Church and confers Vatican approval; it is an instrument "offered to Catholic Bishops and National Episcopal Conferences worldwide as a way to actuate new forms of evangelization"(Argüello, Hernández, and Pezzi 2002, 5-6). This endorsement has put the NCW in the position of being a powerful grassroots movement within mainstream Catholicism, and has facilitated the process of greater public and media engagement by the NCW's leaders, somewhat counterbalancing the longstanding secrecy surrounding written documents. As was the case for the Catholic Charismatic Renewal, the support of Pope John Paul II came about through his acknowledgment of the movement's rather "conservative politics, its militant activism for traditional values and its [. . .] encouragement for contribution to parish activities and finances" (Csordas 2007, 296). The formation of nearly eighty $R e$ demptoris Mater seminaries worldwide, where modern priests are trained under the teachings of The Way but which today formally respond to Vatican authorities, also met Vatican calls for new vocations among Catholic men. Yet, unlike the Charismatic Renewal, individual spirituality and personal relationships with Jesus are highly discouraged, on the premise that a lone person lacks the moral strength and the "appropriate" knowledge to come close to God. Rather, "life within the community" protects people from their own innate weaknesses and sins, thus reasserting a traditional Catholic understanding of the "communitarian relation" with God (Magister 2013). ${ }^{3}$

Despite the formal recognition of the movement by Vatican authorities, controversy within the Catholic Church persists. One of the most contested elements addresses the importance assigned by Kiko Argüello to early Judeo-Christian origins of Catholicism, which has resulted in the insertion of Jewish symbolism into NCW rituals and in huge financial investments in Jerusalem, and Israel more generally, for the construction of NCW seminars, pilgrimage sites, and a (planned) residence to host the Pope. Among fragments of the Catholic Church, this is feared as a (partial) de-centering of Catholicism from Rome to Jerusalem. Throughout 
the 2000s, the House of Nazareth Family in Madrid-officially the residence of Kiko Argüello-and most importantly the Domus Galilaeae in Jerusalem have been increasingly important in orienting the organizational activities of the movement. ${ }^{4}$ Indeed, the life of what Pope Benedict XVI recognized as the "most active and vital presence within Roman Catholicism" (quoted in Argüello, Hernández, and Pezzi 2002, 150) continues to revolve around centers and missionary activities that have remained independent of Vatican control; this fundamental difference of opinion about the importance of location-or of specific locations-has put the movement in prolonged tension with the Catholic Church.

Moreover, many National Episcopal Conferences worldwide conceive the NCW proselytizing mission as inimical to their national authority and as an overbearing intrusion of Vatican central authority into their domains. Priests trained in the Redemptoris Mater seminaries are often not recognized by National Episcopal Conferences, who see their loyalty as given to the movement and to "Kiko Argüello" rather than to appropriately sanctioned authorities. ${ }^{5}$ Members are firmly convinced of the importance of being within mainstream Catholicism—and recognize the Pope in Rome as the highest spiritual authority-but this stance does not seem to diminish the cult of the person of Kiko Argüello. ${ }^{6}$ Kiko Argüello's personal history of loss and redemption as a former atheist, communist, and anticlerical individual not only molds the imaginary of a possible salvation attained through the life course, but also frames the narrative style of those who have entered the movement (Coleman 2000).

The Way thus engages in a multilayered fashion with Catholicism and with contemporary cartographies of religious diversity. Countries where Catholicism constitutes the majority faith-tradition-Italy, Spain, Ireland, and Austria-have been targeted since the outset as crucial destinations of evangelization. Latin American countries, where Catholicism is highly influenced by Liberation Theology, are conceived by the movement as places where the faithful may be gathered back into a Vatican-centered orthodoxy. Yet The Way has also progressively directed its attention to non-European countries, where Catholicism has constituted a minority religion and where it was seen to have "faded" under "more fervent" religions such as Islam or Hinduism. Finally, atheism in post-Communist countries in Eastern Europe and Central Asia was conceived as an overarching "enemy" to be contested. ${ }^{9}$ Overall, the movement has increasingly targeted a heterogeneous population of atheists, Catholic "believers without much involving practice" (Pratt 1996, 76), and devotees belonging to other religions. In all cases the entrance into the movement is officially and experientially conceived in terms of a radical conversion, which formally leaves little space for "cross-fertilization with other religions" or expressions of Catholicism (Csordas 2007, 299). Membership demands the dramatic regeneration of individual spirituality and a break with past "false" and "banal" expressions of faith. It requires 
the Catholic self to become manifest, observable, and validated by other members of the community through everyday practice and sanctioned behavior.

The analysis here draws on seven months of fieldwork conducted in Italy, the United Kingdom, and Turkey with NCW members (priests, families in mission, itinerant families, and parish-based members). ${ }^{7}$ The field locations were chosen so as to conduct research both in places where the movement is well-rooted and "closer" to a majority-faith tradition (like Italy) and in places where the NCW has a more recent history and is in active dialogue with other majoritarian religions (as in the United Kingdom and Turkey). Furthermore, participation in global NCW events allowed me to interact with the experiences of members coming from different worldwide contexts.

I have known of the NCW since 2005, partly through the involvement of relatives and friends in my birth city, Perugia, where the movement is particularly strong. Some of my acquaintances suddenly informed me that they were leaving their jobs and families for good in order to spread "Jesus' message" in China, Romania, and Mali. In 2005 and again in 2009, people I knew-and who had declared themselves secular or atheist-left for Spain to join a mass protest against gay marriages, organized by international members of the movement. During these years, I had many conversations with friends and family who had joined The Way, and occasionally I participated in their weekly celebrations and lifecycle rituals. A latent interest in emerging popular forms of urban devotion resulted in my taking notes and collecting materials for a future project. Interestingly, at this time I had relatively smooth access to the social life of the movement, particularly in my hometown: as a friend hanging around without any formal research role (and being considered a potential convert), I spontaneously came to share personal histories and gain access to weekly meetings. However, from 2011 onwards, my decision to make explicit my intention to conduct research among Neocatechumenals led to tensions in my existing relations. Many of my acquaintances realized that my curiosity was not leading to a conversion, but was rather motivated by what they constructed as an inquisitive gaze from the "scientific world," which was seen as the quintessential expression of secular forces. There are at present no studies of the NCW, and access to its official documents is difficult.

\section{Christian Meanings of Diaspora and Contemporary "Diasporic Catholicism"}

The NCW both finds inspiration in the traditional semantics of diaspora as developed in Jewish and Christian traditions, and actualizes its meaning by introducing novel territorial centers and strategies of dissemination 
of Christian messages. In this respect the movement acts as a potential de-institutionalizing force of consolidated Catholic features and as an architect of new religious cartographies. Studies of diaspora often root the semantics of the term in the Greek colonization of Asia Minor and the Mediterranean during the archaic period and, most saliently, in the Jewish dispersions from Jerusalem (Smart 1987; Cohen 1997; Kokot, Tölölyan, and Alfonso 2004; Safran 2004). The co-option of the Jewish meanings of diaspora by early Christians, even in the first century CE, implied a polemical downplaying of the important aspects of redemption and return, and the obliteration of pre-Christian Jewish diaspora (Baumann 2000; Cohen 1997): the term came to signify the "early Church" as composed of traveling subjects, such as pilgrims and missionaries, who "would function as the seed to disseminate the message of Jesus" without "losing the importance of Jerusalem as the holy land of Christian pilgrimage" (Baumann $2000,319)$, and later a faith community residing in a different confessional environment. ${ }^{8}$

Hammerli emphasizes how the move from Judaism to Christianity implied the weakening of the territorial dimension of diaspora as focused upon a physical center. ${ }^{9}$ Hammerli notes that, for Christians,

[d]iaspora is no more the condition of geographical delocalization, but the exile from the celestial homeland. Territory is relativized by the eschatological expectation of this new, celestial homeland. Thus, all Christians are in a situation of diaspora in this world $(2010,105)$.

This analysis underlines the irreducible distance between Jewish and Christian theological understandings of diaspora: for Christians, the Church is possible everywhere (as the local church expresses the immanent realization of the Body of Christ), ${ }^{10}$ while for Jews, notions of diaspora have territorially been centered upon the importance of the Temple. As Hammerli notes, Christian ecclesiology may invalidate the exportability of the term diaspora to the study of contemporary world Christian communities. But she also notes that the ways in which the Church is expanding and recreating itself in different contexts-as well as the ways Christians (implicitly or explicitly) claim today to be in diaspora-invite scholars to explore the often contradictory co-existence of theological, historical, and contemporary morphologies of religions in diaspora.

While the dispersion and traveling of world religions are taken as what we may call archetypical forms of diaspora (see, for instance, Clifford 1994; Eickelman and Piscatori 1990; Levitt 2003), in current anthropological and sociological analyses the exploration of the potential link between globalizing religions and diasporic formations beyond the migration nexus seems to be marginal. Indeed, there is an underlying 
irony here, insofar as "sociology imported diaspora from theology, but then used it little in relation to faith communities" (Hämmerli 2010, 99). Instead, contemporary disseminations of Christianity are mostly analyzed from the interrelated perspectives of globalization and transnationalism (Beyer 2003; Coleman 2000: Geertz 2005; Huwelmeier and Krause 2010; Menjívar 1999; Sandoval 2001; van der Veer 2001; Vasquez and Marquardt 2003). ${ }^{11}$ While there must be limits for the applicability of the concepts of diaspora (cf. Cohen 1997; Vertovec 2000), the recognition that religions have fundamentally transformed institutional churches can also lead us back to the use of "diaspora" as an analytical device to understand relationships between people, places, and faith beyond the dimensions of migration and ethnicity.

The ethos of reformist Catholicism as embodied in the NCW is framed by a politics of identity that is centered on the recreation of primordial Christian communities, themselves inspired by the life of Judeo-Christians in Jerusalem and the diaspora. Moreover, the historical and geographical importance ascribed to Jerusalem challenges the institutionalized epicenters of Catholicism and Catholics' relations with places and identity: the NCW has actualized the ancient Judeo-Christian semantics of diaspora. By framing membership of the NCW within a narrative of rediscovery of the history and geography of early JudeoChristian life, and by the myth of a common origin that ideally cements the relation between dispersed NCW communities, the movement also speaks to the most critical features of contemporary diaspora, both as a social form and as a type of consciousness (cf. Vertovec 1997). The "fibers of meanings" (Cohen 1997, 180) of the NCW-the expansion from the homeland, the presence of a collective memory, the idealization of the ancestral home, return movements, and complicated relationships with host societies-indicate the terms of contemporary Catholic religious renewal at a global level. The putative rediscovery of early Christian voices-along with their alienation and the troubled relations with secular and religious institutions in the society of residence-indicates that members emphasize the primacy of internal community life over other relations. As a type of consciousness, Neocatechumenals base their collective identity upon the idea of religious journey as a way to return to the origin through the rediscovery of religious awareness (cf. Geertz 1968).

In this context, the nurturing of ancient and present memories of sacrifice may give voice to experiences of discrimination and exclusion. The diasporic elements of the NCW cannot simply be interpreted in terms of spiritual affinity across cultural and territorial specificities, or in travel to holy sites. What is projected is a radical transformation of material and spiritual expressions of religiosity and a substantial political engagement across nations, particularly with issues related to family relations, kinship norms, child and youth education, and sexual morality. 


\section{Designing Diaspora: Itinerant Families and Families in Mission}

The design of reformed Catholic cartographies partly revolves around the activities of itinerant families, who are entrusted with the task of creating and leading new NCW communities worldwide, and of missionary families, who are assigned the role of visiting itinerant ones to provide them with temporary practical and emotional support. While the seventy-two itinerant families that started The Way in the late 1960s were predominantly Europeans, ${ }^{12}$ the last decade has witnessed a (slow) increase in the number of non-Europeans. Becoming an itinerant or a missionary family is a voluntary act, which follows a highly ritualized ceremony named The Standing (L'Alzata), during which Kiko Argüello outlines the targeted destinations and offers directions for the families who are ready to create NCW parishes in the diaspora. The Standing usually takes place during the Itinerant Families World Meeting, usually held in Porto San Giorgio (Italy), or during other internationally relevant events like World Youth Day. As young families stand, Kiko Argüello chooses previously selected destinations at random, assigning each of them to a newly volunteering family. Only later is the list of families and destinations communicated to Vatican institutions.

Both kinds of family remain affiliated to their NCW communities of origin; all are nominated directly by Kiko Argüello and defer to him for important decisions. Thus, while the geographical dissemination of volunteer families results in a flexible network between different NCW communities-and mirrors the movement's politics of spontaneous grassroots action-the encompassing NCW diasporic structure also maintains a centralized and hierarchical nature, insofar as missionary and itinerant families remain de facto subordinated to its leader. Indeed, the fact that missionary activities are not de facto decided and controlled by Rome is distinctive. Whereas traditional Catholic transnationalism was based on the sending of representatives from a politically centralized authority, the NCW, while being itself hierarchical, has adopted more flexible, decentralized, and spontaneous features of Protestant and Charismatic equivalents (Levitt 2003; Rudolph 1997).

In promoting the dissemination of reformed Catholicism through itinerant and missionary families, Kiko Argüello captured one of the main ambitions of the Second Vatican Council: the necessity of the Church to "reconcile a divorce between religion and life" (Argüello 1983: 379; Ferrari 2006). More than priests and sisters, NCW families embody the exemplary life of the Christian family: they are closer to people's mundane concerns and difficulties, and as such they are conceived to be more capable of reaching new converts. Itinerant families hold a generative role within the movement: their duty is to sacrifice existing social relations and relative financial security in their home countries for the sake of participating in the evangelization of other countries. 
The embracing of new loyalties, the construction of strong ties of affective and material dependency ${ }^{13}$ among NCW members, and the choice to live in distant settings all contribute to tensions between missionaries and their families and friends who refuse to enter The Way. This disaffection, in turn, nurtures among itinerant families a form of self-presentation centered on idioms of "true devotion" and of "sacrifice" for The Way. Anna left Perugia in 2007 for Ukraine with her husband, Luca, and lives there with their nine children. During a rare visit to her hometown, she recalled how:

Our parents did not talk to us for long time . . . particularly Luca's father seems to have cancelled him from his life. Luca was a good lawyer before our entrance in[to] the movement .... but now we live out of the help of our sisters and brothers here and also there in Ukraine we are dependent on the community support . . . . It is not easy; there are some periods in which we do not really meet the end of the month . . . but we have faith, we knew that our decision would have put everyone against us . . . . But we were called for this from God, we could not say no even if the people we love do not understand us.

Anna's words are symptomatic of a wider tendency among itinerant families to conceptualize their decisions as an act of love toward God and of dedication to the movement, which nevertheless has brought alienation from their pre-existing social ties. Families are faced with striking a balance between old and new bonds: while new allegiances are deemed to fulfil the search of true religious renovation, a persistent sense of loss and exclusion underpins families' narrations of their broader family and friendship histories.

The movement officially conceives the choice undertaken by itinerant families as radical but not definitive. Families' participation in new diasporic cartographies is officially understood as a transformative act of devotion that requires the sacrifice of pre-existing lifestyles and beliefs. Yet, the movement also contemplates the possibility of return to the home parish, should life conditions abroad prove too difficult. Nevertheless, for the few return families I have met, coming back can also represent a failure and a source of embarrassment with the sending parish, and can lead to a break with the movement.

For those families who do not wish to venture into fully itinerant life, short missions abroad represent a viable solution that allows them temporarily to transcend local parish-based life and connect to the global mission. Missionary families usually offer babysitting, cleaning services, and health care to itinerant families and to the NCW parish as well as to the Redemptoris Mater, where present, and also participate in the teaching of the NCW's rules and the collective reading of the Bible. This temporary support enhances the feeling among itinerant Neocatechumenals that the real source of kin-based sustenance may often come 
from religious sisters and brothers from faraway locations, who travel long distances to cement solidarity.

The work of itinerant and missionary families is meant to solidify a new proximity between reformed Catholic movements-whose centers remain firmly located in the traditional holy places of Christianity, namely the Mediterranean (Italy and Spain) and the Middle East (Jerusalem) and the worldwide Catholic population. In this respect, the mission of new traveling subjects might be described as a "diaspora by design" (Cohen 1997, 184), ${ }^{14}$ as it reflects a colonizing attempt to extend the influence of a (partly) European-centered organization-although the forms voiced and produced by the contextual appropriation of religious streams are not so predictable (cf. van der Veer 1996). In a public speech in Rio de Janeiro during World Youth Day 2013, Kiko Argüello specifically referred to China and India as examples of places where atheism or "other confessions" made people "live without knowing where they are." I watched the video a few days later, in a parish in Perugia, with Neocatechumenals who were praising the appointment of sixty itinerant families bound for China, and thirty for India.

In striking contrast to the past, what I am calling religious colonization happens in a context where the centrality of Rome to Roman Catholicism has been counterbalanced since the 1960s by the emergence of National Episcopal Conferences (Casanova 1997). ${ }^{15}$ These are political bodies designed to mediate between, on one hand, the Roman Holy See and, on the other, Catholic institutions and devotees in their respective national contexts. While National Episcopal Conferences were entrusted by Canon Law in 1983 with the right to establish their own Statutes and to handle national religious questions, their national sovereignty is de facto limited by their dependence on the Vatican for questions of doctrine as well as those of "international relevance." ${ }^{16}$ Indeed, the globalization of the NCW should be partly understood in terms of a post-Conciliar tension between the projected (re-)internationalization of Rome and the Romanization of world Catholicism, on one hand, and the centralization of Catholic churches at the national level, on the other. The movement embodies the post-Conciliar ethos of spreading reformed Catholicism through grassroots activities worldwide, although it remains simultaneously structured around the centrality of Rome and of NCW holy centers.

Yet the diffusion of the Neocatechumenal Way from an idealized homeland has to confront the institutionalized presence of the National Episcopal Conferences as national political and religious bodies. The tensions surrounding NCW diasporic cartographies emerged between 2011 and 2013, when the movement was officially banned by the National Episcopal Conference on the grounds that it posed a threat to national culture and identity; it was subsequently re-imposed in the country by Vatican decree, under the pressure of NCW representatives. $^{17}$ National Episcopal Conferences have the formal power to demand, accept, or reject the presence of the movement, although 
these choices seldom reflect a unitary decision. In many cases, the acceptance of itinerant families at the level of archdioceses does not meet the approval of the National Episcopal Conferences, or vice versa, which creates tension between the two authorities and with the Vatican. The controversy between the Japanese National Episcopal Conference and the Vatican, for example, has shown not only the centrality of Rome as a Catholic homeland but also, and perhaps more importantly, how the development of a renewed diasporic configuration through missionary activities has given the NCW the power to influence the Vatican in opposition to national Catholic bodies.

The crucial role of itinerant and missionary families must thus be understood in the context of the increasing multi-centeredness of the cartography of Catholic belonging (cf. Coleman 2000), which reflects a dialectic between institutionalized centers of this religion (Rome) and new configurations of the homeland by virtue of the creation of new centers (Madrid, Porto San Giorgio), or the re-actualization of others (Jerusalem). The (partially) fluid quality of the NCW combines the recognition of both kinds of centers of centralized authority - the Vatican in Rome, the emergent centers of the movement in Italy and Spain, and the Domus Galilaeae in the Holy Land-with the multilayered identifications that are inherent in relatively flexible transnational activities. Ultimately, tensions between different expressions of Catholic belonging (local, national, transnational, global), and the resulting stigmatization or popular debate surrounding NCW activities, nurture among itinerant and missionary families and more generally among NCW members a sense of being in diaspora-independent from the locations of their activities - as well as a sense of collective discrimination.

\section{Critique of Catholic Institutionalization and Material Recreation of the Homeland}

Over the last decade, the NCW has welcomed its institutionalization within Catholicism, but its strategy challenges the relationship between Catholic authorities and local or community life. Kiko Argüello argues that a reformed religiosity cannot prescind from a radical reconsideration of Catholicism within countries where it historically represented the majority faith tradition. Existing Catholic institutions and community life are deemed to have been increasingly secularized, corrupt, and lacking charismatic leadership, such that the majority religion is thought to have become a "formal subscription to empty rituals and formal celebrations (Argüello 2013: 24)." The emphasis placed on the need for a purified Church has become particularly evident in the aftermath of scandals related to pedophilia.

While Kiko Argüello has moved in a contradictory way between the defense of Catholic institutions and the condemnation of sinful practices, many of the members I have interviewed saw these events as 
symbolic of Catholic institutional degeneration and itinerant families as a potential source of recuperation. Most NCW members agreed on the need to invest itinerant missionaries and their mobile community life with more authority than the parish priest. Thus, significantly, even Catholics residing in Catholic countries are considered far from the possibility of true Christianity, while devotees living as minorities worldwide-and who feel neglected and misunderstood by the institutions that claim to represent them-are closer to the center through becoming members of The Way. Interviewees of many different nationalities often referred to one of the main slogans of the movement- "The Way is for those abandoned in their own countries"-to underline their sense that they could not be fully represented by established Catholicism.

Indeed, Catholics who wish to enter the movement have to accept a virtual return to atheism and the invalidation of any Catholic ritual and habitus practiced before the moment of conversion. The intended move from "religiousness" to "religious mindedness" (cf. Geertz 1968, 2005) implies the invalidation of existing Catholic life and loyalties; this renunciation intentionally creates a sense of distance from institutionalized Catholicism. As one of the founders of the movement, today itinerant in France, stated:

In our countries we are not understood, people think that we are fanatics because their minds have been obfuscated by material concerns and by a Church made of ceremonies, speeches, ignorant subscription to rituals. . . they think that it is enough to go to Church . . . . But for those in Jerusalem, being Christians meant a way of life, of common love and sharing. . . they travelled the world to make Christ known and they did so by giving the example.

Similarly, in an interview released to a Spanish Catholic radio station, Kiko Argüello has emphasized how:

The normal pastoral care-mass, catechesis, etc.-is for religious persons, but is no good for modern man, who is secularized, half atheist, socialist, etc. Those religious services are not effective; a sign is necessary. The sign is the call of the primitive Church: "See how they love each other." That call appears again in the modern secularized Church. How? Creating a parish community that gives those signs: "as I have loved you." (Argüello 2010)

These passages evocatively represent the crucial identification of the new start with the life of Judeo-Christians and with their exemplary translation of religion into a way of life. The only way to instill true religiosity in secularized men and women is not through formal religious education or ordinary parish life but through a return to a re-imagined and actualized past when Christianity ideally signified the sharing of everyday life and fraternal love. The actualization of Judeo-Christian origins is carried out by the NCW through the formation of small 
communities within existent parishes, each composed of fifteen or twenty families. The acceptance of The Way creates a break with conventional parish life, as the movement literally colonizes the parish through a series of diffuse activities, as well as by imposing its liturgy during the mass. One member of an itinerant family quoted a recurrent expression of Kiko Argüello's: "Our role is to create confusion within parishes and to shake people's lives." Among the most contested or radical issues are the placing of the altar in the center of the church, the presence of the menorah (Jewish candelabra) on the altar, the use of Azim bread rather than the host, and the priest going to devotees rather than the other way around during the communion.

Frequent internal conflicts with non-NCW parishioners, and the perennial possible banning of The Way, reinforce the sense of being a minority within a hostile Catholic environment. Each community is forged upon what the movement's founders reinterpreted as the model life of early Judeo-Christian communities, that is, the guidance of elder and more expert members (presbyters), ${ }^{18}$ everyday prayer and meal sharing, acceptance of routine activities like cooking or cleaning, helping families in need or educational services to children and youth, regular religious instruction in the Old and New Testaments, and the acceptance of community authority in family and personal life. The acceptance of this life model is what allows the recreation of a mythicized past and the present return to pure Judeo-Christian origins. People entering The Way are familiarized with the history of early Christianity and the contents of the Torah by historians or theologians who belong to the movement. Collective reading of religious texts is guided by itinerant families — or the single community guide - who prompt members to actualize the meanings of biblical scripts for modern times.

Each community is encouraged to generate new itinerant families as a way to care for those people not yet reached by "the message." This goal emerges clearly in the words of one member of the NCW in a London-based parish:

It is not just a matter of living the parish, you see. . . to share the world and life of Christ with people here .... Early Christians had a project, had a mission, they were not just happy with their life in $\mathrm{Pa}$ lestine. . . they cared for those who had not receive the light yet, who were far away. . . so, we need to care for those who are far away from Jerusalem, from the true way. We have here trained one family to go to Scotland now, and another one is leaving for Sri Lanka soon.

Significantly, what is seen as the individualism of parish life within institutionalized Catholicism is contrasted with the connective capacity of the movement to recreate interrelated communities worldwide. The formation of novel NCW communities worldwide represents one of the most important activities through which parishes can be revitalized, by showing concern toward the Catholic world beyond the locality. 
Translocal connectivity aims at infusing a new sense of belonging into what is deemed to have been forgotten or underplayed among Catholics, that is the genealogical link with Jerusalem and Jewish origins.

Once settled in the new context, itinerant families-with the support of presbyters-organize the evangelization of families in hierarchical stages toward "The Truth." Formally, there are three main phases in the progressive life of each community, and each is subject to the scrutiny of the elders and itinerant families. The first phase is called the precatechumenate and begins with kenosis, addressing the descent into the humble acceptance of God's community life. Each member agrees to donate a tenth of their salary as maaser (the Jewish offering to the temple). The first scrutiny leads to the Shema, a word taken from Jewish tradition to indicate the acceptance of faith in God and the willingness to pray collectively twice a day. The second scrutiny leads to the second phase, which sanctions the effective entrance into the reading of biblical text and the receiving of the Liturgia delle Ore (prayer guide). The third phase is the culmination of The Way toward the purification of sins and the rediscovery of real Christian life, sanctioned by the pilgrimage to Jerusalem and baptism in the Jordan River. The passage from one stage to another and the final symbolic return to Jerusalem cannot be attained individually, but must be the result of a collective process of purification. If one member of the community fails to move from one stage to the next, the whole community is "blocked" and has to wait for the person to recover from his or her sin.

\section{Collective Sacrifice and Symbolic Return}

Members consider entering The Way as an act of conversion that places them in opposition to the surrounding society. NCW politics of self-presentation are indeed molded by concepts of sacrifice, victimhood, and courage that materialize in the NCW's attempts to convert "hostile" and "blind" families who have remained distant from "The Truth." During the 2013 World Youth Day, Kiko Argüello publicly depicted the "world Neocatechumenal family" as a persecuted group:

We have been discriminated [against]. . . . How many times have we been kicked off from our parishes, our countries, like in Japan, in Peru ... . Before the Vatican II, people like me could have never have preached like I am doing now, but our persecution continues. It is a miracle we are all united here now, but we will be kicked out more and more, we do not know for how long we will be here. ${ }^{19}$

Mass celebrations or annual meetings often begin with the recollection of how difficult members' lives are worldwide due to the lack of support they receive from Catholic institutions and to perceived state persecution. 
During his visit to Rome for the Holy Family Day in 2011, Thomas (an Indian NCW member active in the Bangalore Redemptoris Mater and parishes) recalled the persecution undergone by NCW members in Karnataka. He addressed a specific episode in 2008, when a group of Neocatechumenals were assaulted by the RSS (the pro-Hindutva militant organization) in Northern Karnataka for having stopped in villages on their way back to Bangalore to preach Christ's message. Subsequently the NCW were prosecuted for violating the anti-conversion legislation adopted in several Indian states. As Thomas put it:

We have to remember that every act we do in order to bring into life the message will make us attacked and derided by those who are far from us and that our brothers and sisters worldwide are persecuted by our states for their activities.

Indeed, it is often the secular state and the isolation from the wider Catholic world that become the targets in NCW critique. Indeed, during the same meeting Italian families and Indian representatives discussed how NCW priests in Italy were taken to court during the referendum on assisted reproduction (2005) for having embraced openly political stances during the mass, or how members were prevented by the police in London or Rome from proselytizing to passersby.

Alongside the recreation of idealized origins, the daily struggle against a hostile society enhances the possibilities of rejoining the homeland and of a new birth. In reproducing the material life of early Judeo-Christian communities, the NCW invokes the centrality of Jerusalem in the diasporic imagination and becomes symbolically closer to a past that is deemed to have been lost with the institutionalization of the Catholic Church. Jerusalem has different meanings in the NCW politics of identity and in the framing of a diasporic consciousness. It is the land that inspires NCW community life and guides members toward progressive individual and family purification and toward the achievement of a more truthful spiritual stage. It is a destination that has to be deserved, and that ideally should be visited at the end of a guided process of regeneration. In reframing the centrality of Jerusalem in Catholic cartographies, Kiko Argüello is active in what could be defined as a folk attempt at crossing the borders between Judaism and Christianity (cf. Boyarin 1999) to re-center Catholic religiosity in its territorial and historical origins. This effort implies a double exercise of collective memory. On one hand, religious trajectories are framed around the recalling of histories pertaining to the life of early Judeo-Christians. On the other, present conflicting relations worldwide are recalled as reiterative of the sacrifice made by ancestors to disseminate Christ's message. The return to the Holy Land of Jerusalem is in the first place understood as a teleological journey: the structure of NCW communities in a limited number of families, the daily sharing of meals and praying, and the use of Jewish symbolism in daily rituals are 
meant to actualize in the everyday the mythicization of ancestral origins. In another (equally important) sense, the completion of The Way by the whole community is sanctioned by the return to Jerusalem as deserving devotees who can receive baptism in the Jordan River. Significantly, any pilgrimage to the Holy Land is highly discouraged before the end of The Way, as the return to the Jordan can be achieved only by those who have embodied in their path the life of early Christians. ${ }^{20}$ We can thus speak of two interrelated projects of return: one implied in the re-creation of the ethos of early Christianity among scattered communities, and the other in the collective movement toward the return to Jerusalem as achieved at the end of The Way. Both projects ideally thread together the life of communities that are at the same stage in The Way. Alfonsa, a Catholic woman from Mexico City, was sent with her husband and five children to Rome to represent her parish and the NCW in Mexico during Holy Family Day. ${ }^{21}$ This event is meant to allow communion and exchange between all families, and activities are organized in such a way as to bring together families to discuss specific problems encountered during their missions. In an informal conversation, Alfonsa said:

See, before I entered the Way I was feeling [very] alone and I was not even thinking of having a family, but now you have the feeling you are like moving towards something, something that it is bigger than you and that you cannot complete alone .... It is not easy, as people do not understand and they call us crazy, but then I think that there are other families here that are going through what I am going, and whom I will meet in Jerusalem when the elders will decide that we have passed the scrutiny, when I will deserve . . . . So when I think [of] this, [of] all the families in the Way and to the future Baptism, I just find the strength . . . . During our meetings we choose the readings from the Old Testament decided by the Catechesis of Kiko, we have our candelabra, our unleavened bread and we all pray together, and we dance, and I think that I am getting closer and closer.

Alfonsa's statement points to how, ideally, the reading and discussion of biblical scripts by worldwide members at the same stage follow the selections and indications of the catechesis written by Kiko Argüello, cementing a sense of unity and of collective movement toward the end of the journey. Her account further stresses how this closeness is nourished by the symbolic use of objects taken from the Jewish tradition-a distinctive feature of the NCW-that come to signify the final destination of The Way. The importance of Jerusalem is also materialized in the recurrent presence of objects such as the menorah ${ }^{22}$ or of the wooden bimah ${ }^{23}$ in NCW parishes and Redemptoris Mater seminaries.

The last decade has witnessed an event considered by many devotees as the geographical rapprochement of Catholicism and Judaism. In 2000, the Domus Galilaeae-an impressive construction built on the Mount of Beatitudes-was inaugurated by Kiko Argüello to host a 
Redemptoris Mater, promote Catholic and Jewish educational and ecumenical activities, host the Pope during his visits, and welcome NCW families from all over the world to celebrate reaching the end of The Way. In the presence of Jewish, Catholic, and other Christian representatives, Kiko Argüello stated that the architecture of the Domus and the presence of the Torah and of other important Jewish religious elements constituted the recognition of the "common heritage of world Catholics to its origins," and that "the Domus should represent a bridge between Judaism and Catholicism" (Magister 2004). The inauguration was formally welcomed by Pope John Paul II but it also exacerbated ongoing controversies about the potentially heretical status of the NCW. The historical, ritual, and material emphasis placed on Judaism by the NCW has been accused by some National Episcopal Conferences and Catholic Association representatives of misusing Judaic symbols, thus offending Jewish devotees (Magister 2005); downplaying how Jewish origins of Christianity are already recognized within Catholic orthodoxy; ignoring the historical independence and autonomy achieved by the two religions (Magister 2005); and wanting to delegitimize Rome as the center of global Catholicism in order to "transfer the Vatican to Galileae" (AA.VV 2006).

\section{Conclusion: New Catholic Diasporas}

This article has started to explore the contemporary phenomenology of the Christian diaspora by taking as a case in point a Catholic movement that aims at reshaping the cartography of this religion and at deeply transforming the relation between devotees and places. ${ }^{24} \mathrm{My}$ intention has been to outline how the spread of a reformist religious movement at a global level speaks to current understandings of diaspora both at semantic and phenomenological levels. The ways in which this form of Catholicism exists today in diaspora-through the spreading of itinerant and missionary families-invite us to reconsider how it is that the notion of diaspora applies to the contemporary formations of world religions.

Catholicism is arguably one of the most firmly established and institutionalized religions in the world. But we must not assume that Catholics living in countries where Catholicism represents a majority faith tradition will subscribe to the existing establishment, or that Catholic minorities are well represented worldwide by their National Catholic Churches (Episcopal Conferences). Nor should we take the dissemination of the Catholic message as a unilateral expression of longstanding transnationalism that always complies with the norms and expectations of its center. These assumptions about the traditionalism and institutionalization of the Catholic Church have made Catholicism, to paraphrase Casanova, "the most understudied religion in social sciences" (1994, 235), particularly 
when compared with Evangelical churches or Protestant Charismatic Christianity.

By contrast, the NCW exemplifies projects of reinvention of elements of a Christian diaspora - as a frame and a form — by giving them modern meanings in the present. The movement both instills and voices a persistent sense of distance from Catholic institutions and a return to the real origins of Christianity, through the re-creation and dissemination of NCW communities worldwide. These communities conceive their religious affiliation in opposition to the secular world and the mainstream religious establishment. In turn, this oppositional identity forges both a sense of common sacrifice for the regeneration of religious life, and a commitment to a cause in which the life of individual communities is melded with the life of brothers and sisters worldwide. Community life and reciprocal dependency between NCW members, as a material and symbolic project of religious journey toward the Domus Galilaeae in Jerusalem, is a crucial element in cementing a diasporic identity beyond spiritual affinity. Indeed, in participating in mass protests or in the life of other communities, what is produced is not only a sense of belongingor a diasporic consciousness-but a new orthodox project to transform the world of Catholic life.

\section{Acknowledgements}

This paper was presented at the "Religion in Diaspora" Conference, Wadham College, Oxford University, July 11-12, 2012. I am grateful to David Gellner, Sondra Hausner, Jane Garnett, Nick Van Hear, Robin Cohen, Jonathan Boyarin, Simon Coleman, Linda Woodhead, and Kristine Krause for involving me in a stimulating debate on the relation between religion and diaspora, and for their useful comments on earlier versions of this article.

Ester Gallo is a Lecturer in Anthropology at the University of Trento and Research Fellow at the Robert Schuman Centre for Advanced Studies (RSCAS), European University Institute, Italy.

Notes

1 All names have been changed to protect the anonymity of those interviewed.

2 I use the term Catholic Church here to refer to the ensemble of National Episcopal Conferences, the Catholic Community, and their mutual transnational relations. I use the term Vatican to refer to the sovereign government of the Vatican City. These two political entities are of course overlapping.

3 It is also possible that the relation between the movement and the Vatican will change with Pope Francesco I, particularly after his official speech against proselytism, but this will of course require further investigation.

4 During World Youth Day in Madrid in 2011, the House of Nazareth Families was visited by many families (also non-Catechumenal) and hosted many official talks and meetings between pilgrims and national and international Catholic representatives. 


\section{Diaspora 19:1 (2010) / published Fall 2016}

5 In 1996, the then Archbishop of Westminster and President of the English and Welsh Episcopal Conference refused to celebrate the ordination of sixteen seminarists trained in Redemptoris Mater seminaries. They explained this decision by stating that NCW-trained priests respond more to the heads of the movement than to their own bishops.

6 In this respect, the NCW shows similarities with Protestant Charismatic movements or the Restorationist Christian Mormons (Coleman 2000; Cannell 2005).

7 Research with NCW communities was conducted in Rome and Perugia (2011, two months; 2013, two months), London (2011, one month), and Istanbul and Antakya (Turkey, April-May 2012, two months). Additionally, research included a total of eleven interviews with itinerant families of different nationality currently in mission in the United Kingdom (one), France (one), Germany (one), India (two), Zambia (two), Romania (one), Turkey (one), and Ukraine (one); three interviews with NCW priests; and twenty interviews with NCW members of different ages living in Perugia (6), Istanbul (two), Antakya (five), Rome (two), London (one), Bangalore (three), and Mexico City (one). In addition, I took part as an observer in the NCW's organization of the 2011 and 2013 World Youth Days, in the Itinerant Families World Meeting in Porto San Giorgio (September 2011), and the Holy Family Day in Rome (December 2011). Video materials about Kiko Argüello's speeches and interviews were kindly shared by some members of the group. Watching these videos with them provided many occasions for discussion and confrontation and also softened defensive attitudes arising during other more formal interviews.

8 Baumann notes that studies of Christian diasporas have often remained historically descriptive and lacking in analytical focus on its contemporary forms (2000), resulting in under-theorization of the socalled "religious diaspora" (cf. Cohen 1997).

9 Smart links "religious diasporas" to the effects of globalization, especially as it allows devotees to reconnect through travel, media, or pilgrimages to the holy centers of their religions, including, for instance, the relation between Catholics and sacred sites such as Rome or Lourdes (Smart 1987). By contrast, Hinnells defines "diaspora religion" as a "group of people who develop a sense of living away from the land of their religion" (1997, 184-5): if Christianity can be considered diasporic, its Catholic and Protestant avatars would not fit the definition, because their institutionalization in (multiple) Western countries no longer leads people to feel displaced from the country of their religion.

10 Similarly, Colucciello-Barber adopts the concept of diaspora to explore the de-territorializing character of Christian declaration and the "tension between the Christian discourse and the discourses of the host countries" $(2011,76)$.

11 The progressive linking of diaspora studies with migration and post-migration (Vertovec 2000) that accompanied the "dislodging and semantic broadening" (Baumann 2000, 320) of the concept from its original formulations has effectively relegated diasporic aspects of Christianity to an ancient past in scholarly circles—as well as in NCW ones.

12 They also constitute part of the NCW International Equip.

13 In terms of material dependency during their missions, itinerant families and, to a more limited extent, missionary families accept dependence on economic support from the NCW members of their original parish.

14 Cohen uses the phrase to refer to the worldwide expansion of Europeans for political and economic domination. While rooted in colonialism, this "label increasingly gained currency in the age of globalization" (1997, 184).

15 The National Conference of Bishops has a long informal history but was officially established as a National Institution by Vatican II.

16 See the 1983 Canonical Law, Part II, Section II, (Cann. 249, and 368-572).

17 In 2010 the movement was banned in Japan by the Japanese Episcopal Conference, due to the opposition of some bishops. The latter considered the activity of itinerant families as incompatible with national culture and family values. Source: L' Osservatore Romano, 15 June 2011 . The Way was 


\section{Multiple Allegiances and Belonging in Global Catholicism}

then reintroduced in Japan in January 2013 at the request of the Vatican. This was taken by the Japanese National Episcopal Conference as a violation of its own national authority. See $L$ ' Osservatore Romano, 31 March 2013.

18 Each community has an elder who belongs to the community of residence. By contrast, itinerant families belong to their original community but are responsible for all the communities within the parish, or within a wider geographical area.

19 This is taken from my notes during Kiko Argüello's speech during World Youth Day in Rio de Janeiro, 29 July 2013. Official Neocatechumenal Video.

20 This baptism is de facto considered the first baptism, and as the starting point of a new evangelical mission for those who have completed The Way.

21 The journey from a distant location is usually paid for by two kinds of fundraising: first, by the local community and fellow national communities and, second, by resources collected worldwide and controlled by Kiko Argüello and International Equip.

22 This nine-branched candelabrum is used on the Jewish holiday of Hanukkah.

23 This elevated platform is usually placed in the center of the synagogue for the reading of the Torah.

24 This is one of the aims of the research I am currently undertaking in Antakya and Istanbul.

25 Argüello $(2013,130)$.

\section{References}

AA.VV. 2006. "Le stranezze liturgiche dei Neocatecumenali [The strange liturgies of the Neocatechumenals]." http://www.internetica.it/neocatecumenali/stranezze-liturgiche.html

Argüello, Kiko. 1983. "Official Discourse at the Plenary Assembly of the Vatican Congregation for World Evangelization." In Il Cammino Neocatecumenale nei discorsi di Giovanni Paolo II e Benedetto XVI (con Appendice contentente i discorsi di Kiko Argüello) [The Neocatechumenal Way in the Discourses of John Paul II and Benedict XVII (with an Appendix including discourses of Kiko Argüello)], ed. AAVV. Rome: Pubblicazioni Centro Neocatecumenale.

Argüello, Kiko. 2010. "Interview with EWTN." http://www.camino-neocatecumenal.org/neo/iniciadores \%20camino/entrevista\%20kiko\%20ewtn\%20ingl.htm.

Argüello, Kiko. 2013. Il Kerigma. Nelle baracche con I Poveri [The Kerigma: In the shacks with the poor]. Rome: Edisioni San Paolo.

Argüello, Kiko, Carmen Hernández, and Mario Pezzi. 2002. Il Cammino Neocatecumenale: Statuto [The Neocatechumenal Way: The Statute]. Rome: Edizioni San Paolo.

Baumann, Martin. 2000. "Diaspora: Genealogies of Semantics and Transcultural Comparison." Numen 47 (3): 313-337. http://dx.doi.org/10.1163/156852700511577.

Beyer, Peter. 2003. "De-centering Religious Singularity: The Globalisation of Christianity as a Case in Point." Numen 50 (4): 357-386. http://dx.doi.org/10.1163/156852703322446651.

Boyarin, Daniel. 1999. Dying for Gods: Martyrdom and the Making of Christianity and Judaism. Stanford: Stanford University Press.

Cannell, Fenella. 2005. "The Christianity of Anthropology." Journal of the Royal Anthropological Institute 11 (2): 335-356. http://dx.doi.org/10.1111/j.1467-9655.2005.00239.x. 


\section{Diaspora 19:1 (2010) / published Fall 2016}

Casanova, Jose. 1997. "Globalizing Catholicism and the Return to a Universal Church.” In Transnational Religion and the Fading States, ed. S.H. Rudolph and J. Piscatori, 121-42. Boulder, CO: Westview Press.

Clifford, James. 1994. "Diasporas." Cultural Anthropology 9 (3): 302-338. http://dx.doi.org/10.1525/ can.1994.9.3.02a00040.

Cohen, Robin. 1997. Global Diasporas: An Introduction. 1st ed. London: UCL Press. http://dx.doi.org/ $10.4324 / 9780203228920$.

Cohen, Robin. 2008. Global Diasporas: An Introduction. 2nd ed. Abingdon: Routledge; http://dx.doi. org $10.4324 / 9780203228920$

Coleman, Simon. 2000. The Globalization of Charismatic Christianity. Cambridge: Cambridge University Press;. http://dx.doi.org/10.1017/CBO9780511488221.

Csordas, Thomas J. 2007. "Global Religion and the Re-Enchantment of the World: The Case of the Catholic Charismatic Renewal." Anthropological Theory 7 (3): 295-314. http://dx.doi.org/10.1177/ 1463499607080192

Eickelman, Dale, and James Piscatori. 1990. Muslim Travelers: Pilgrimage, Migration and the Religious Imagination. London: Routledge.

Ferrari, Lisa. 2006. "The Vatican as a Transnational Actor." In The Catholic Church and the Nation State: Comparative Perspectives, ed. P.C. Manuel and C. Wilcox, 33-49. Washington, DC: Georgetown University Press.

Geertz, Clifford. 1968. Islam Observed: Religious Developments in Morocco and Indonesia. Chicago: Chicago University Press.

Geertz, Clifford. 2005. "Shifting Aims, Moving Targets: On the Anthropology of Religion." Journal of the Royal Anthropological Institute 11 (1): 1-15. http://dx.doi.org/10.1111/j.1467-9655.2005.00223.x.

Hämmerli, Maria. 2010. "Orthodox Diaspora? A Sociological and Theological Problematization of a Stock Phrase." Intermational Jourmal for the Study of the Christian Church 10 (2-3): 97-115. http:// dx.doi.org/10.1080/1474225X.2010.510789.

Himes, Kenneth. 2006. "Vatican II and Contemporary Politics." In The Catholic Church and the Nation State: Comparative Perspectives, ed. P.C. Manuel and C. Wilcox, 16-31. Washington, DC: Georgetown University Press.

Hinnells, John. 1997. “The Study of Diaspora Religion.” In The New Penguin Handbook of Living Religions, ed. J. Hinnells, 682-89. London: Penguin.

Huwelmeier, Gertrud, and Kristine Krause. 2010. "Introduction." In Traveling Spirits: Migrants, Markets and Mobilities, ed. G. Huwelmeier and K. Krause, 1-16. London: Routledge.

Kokot, Waltraud, Khachig Tölölyan, and Carolin Alfonso. 2004. "Introduction.” In Diaspora, Identity and Religion: New Directions in Theory and Research, ed. W. Kokot, K. Tölölyan, and C. Alfonso, 1-8. London: Routledge.

Levitt, Peggy. 2003. “You Know, Abraham Was Really the First Immigrant': Religion and Transnational Migration.” International Migration Review 37 (143): 847-74.

Magister, Sandro. 2004. "Il Vaticano Muove alla Scoperta di Israele [The Vatican sets out to discover Israel].” L'Espresso Online: http://chiesa.espresso.repubblica.it/articolo/7043

Magister, Sandro. 2005. "Messianismi paralleli: gli ebrei Lubavitcher e i neocatecumenali [Parallel messianic forms: Lubavitcher Jewish and the Neocatechumenals]." L'Espresso Online: http://chiesa. espresso.repubblica.it/articolo/22847 


\section{Multiple Allegiances and Belonging in Global Catholicism}

Magister, Sandro. 2013. “No To Proselytism. Yes to Mission.” L'Espresso Online: http://chiesa.espresso. repubblica.it/articolo/1350625?eng=y

Menjívar, Cecilia. 1999. "Religious Institutions and Transnationalism: a Case Study of Catholic and Evangelical Salvadorian Immigrants.” International Journal of Politics Culture and Society 12 (4): 589-612. http://dx.doi.org/10.1023/A:1025990209941.

Pratt, Jeff. 1996. “Catholic Culture.” In Italian Cultural Studies: An introduction, ed. D. Forgacs and R. Lumley, 129-44. Oxford: Oxford University Press.

Rudolph, Susan H. 1997. “Introduction: Religion, States and Transnational Civil Society." In Transnational Religion and the Fading States, ed. S.H. Rudolph and J. Piscatori, 1-19. Boulder, CO: Westview Press.

Safran, William. 2004. "Deconstructing and Comparing Diasporas." In Diaspora, Identity and Religion: New Directions in Theory and Research, ed. W. Kokot, K. Tölölyan, and C. Alfonso, 9-29. London: Routledge.

Sandoval, Efren. 2001. "Catholicism and Transnational Networks: Three Cases from the MonterreyHuston Connection.” In Transnational Immigrant Networks, ed. H.R. Ebaugh and J.S. Chafetz, 93109. Walnut Creek, CA: Altamira Press.

Smart, Ninian. 1987. "The Importance of Diasporas.” In Gilgul: Essays on Transformation, Revolution and Permanence in the History of Religions, ed. R.Y. Shaked, D.D. Werblovsky, G.A. Shulman, and G. Strounk, 288-95. Leiden: Brill.

van der Veer, Peter. 2001. "Transnational Religion.” Paper given at the Conference on Transnational Migration: Comparative Perspectives, Princeton University. Transcomm Working Paper WPTC-01-18.

van der Veer, Peter, ed. 1996. Conversion to Modernities: The Globalization of Christianity. London: Routledge.

Vasquez, Manuel, and Marie Marquardt. 2003. Globalising the Sacred: Religion across the Americas. New Brunswick, NJ: Rutgers University Press.

Vertovec, Steven. 1997. “Three Meanings of 'Diaspora,' Exemplified among South Asian Religions.” Diaspora 6 (3): 277-299. http://dx.doi.org/10.1353/dsp.1997.0010.

Vertovec, Steven. 2000. "Religion and Diaspora." Paper given at the Conference on New Landscapes of Religion in the West, University of Oxford, 27-29 September. http://www.transcomm.ox.ac.uk/working $\% 20$ papers/Vertovec01.PDF

Wolffe, John, ed. 2002. Global Religious Movements in Regional Contexts. Burlington, VT: Ashgate. 
Copyright of Diaspora: A Journal of Transnational Studies is the property of University of Toronto Press and its content may not be copied or emailed to multiple sites or posted to a listserv without the copyright holder's express written permission. However, users may print, download, or email articles for individual use. 